Reprod. Nutr. Dévelop., 1980, 20 (4 B), 1285-1307.

\title{
Intestinal absorption of triglycerols
}

\author{
par Jacqueline CLÉMENT
}

Laboratoire de Physiologie animale et de la Nutrition

U. E. R. Nutrition, B P 138, 21004 Dijon Cedex, France.

Summary. Triglycerides are insoluble in water and the major function of the digestive processes is to convert them into more polar forms. This transformation occurs in the small intestinal lumen by the action of lipase, in the presence of colipase, at the oil-water interface. Pancreatic lipase releases the fatty acids located at the 1 and 3 positions of the triglycerides to form 2-monoglycerides; this enzyme can only hydrolyze 25 to 50 p. 100 of the latter.

The free fatty acids and 2-monoglycerides resulting from lipolysis are solubilized in the bile micelles to form mixed micelles. Transfer from the lipids of the lumen to the absorptive cell membrane is opposed by the diffusional resistance of the unstirred aqueous layer coating the intestinal epithelium.

Fat absorption occurs rapidly in the duodenum and jejunum ; monoglyceride absorption is higher in the tip cells than in the crypt cells.

In the smooth endoplasmic reticulum, triglycerides of the intestinal mucosa are biosynthesized (i) from free fatty acids which acylate endogenous glycerophosphate via phosphatidic acids and 1.2 diglycerides (the glycerol released after lipolysis of dietary triglycerides was not extensively used for this biosynthesis), (ii) from 2-monoglycerides by direct esterification and (iii) from 1-monoglycerides by phosphorylation via lysophosphatidic acids. Before fatty acids are used for acylation reactions, they must be converted to their corresponding CoA derivatives.

The resynthesized triglycerides accumulate within the Golgi apparatus where chylomicrons are formed by the addition of phospholipids and proteins (previously synthesized in the rough endoplasmic reticulum), cholesterol and sugars. Chylomicrons in the Golgi vesicles are secreted into the intercellular spaces by exocytosis, then travel through into the lamina propria and the lymphatics.

In fact, the resynthesized triglycerides are transported in the lymph by chylomicrons and very low density lipoproteins ; particle sizes range from 0.05 to $0.75 \mu \mathrm{m}$ in diameter. The triglycerides form the core of these particles, while the phospholipids, cholesterol and proteins appear to surface-coat the core ; the chylomicron proteins ( 0.5 to $2 \mathrm{p} .100$ in mass) are of considerable importance in their formation and transport. The apoproteins of these in the rat are ; apo A (7 p. 100), apo B (20 p. 100), apo C (70 p. 100) and apo E (3 p. 100). The first two apoproteins are synthesized by the enterocytes while apo $C$ would be brought by plasma very high density lipoproteins.

The phospholipids in chylomicrons are mainly of endogenous origin ; the cholesterol derives from many sources (diet, blood, digestive secretions, new synthesis in the enterocytes) and the triglycerides contain both endogenous and exogenous fatty acids. The endogenous lipids are derived from blood circulating through the intestinal mucosa, bile, desquamated intestinal epithelium cells, or are newly synthesized by the enterocytes. They are added to dietary fats and undergo the same processes as the latter.

The dietary triglycerides containing short and medium-chain fatty acids have a special behaviour. In the intestinal lumen, these fatty acids are rapidly released by pancreatic lipase regardless of their position in the triglyceride molecule. As their polarity is higher 
than that of long-chain fatty acids, these unesterified fatty acids are absorbed directly without belonging to mixed micelles, and easily cross the unstirred layer. They are bound to plasma albumin and transported mainly by the portal vein. When their chain is shorter, higher amounts are transported by the portal blood; when their chain is longer, larger amounts are incorporated into the triglycerides and enter the lymph.

\section{Introduction.}

Triacylglycerols, usually referred to as triglycerides, are the main lipids in diefary fats such as cream, butter, oil and margarine. We know that after they are ingested, the chyliferous vessels become milky and that most of the lipids transported by the chyle are also triglycerides. Since these lipid components are insoluble in aqueous media, the function of the digestive processes is to transform them into more polar forms. It is thus necessary to explain their absorption through the intestinal epithelium, then de novo triglyceride synthesis in the enterocyte, and finally chyle transport of the triglycerides.

In this report I shall, only discuss present theories*.

This article is arbitrarily divided due to the relationship of certain facts, as for example, pancreatic lipase action and the physico-chemical state of intraluminal lipids, the morphology of the intestinal mucosa and triglyceride resynthesis, chylomicron formation.

\section{Digestion}

\section{A. - Biochemical processes.}

Gastric stage. - The triglycerides reach the duodenum in a practically unmodified state. However, since 1900, several authors have reported lipolytic action in the stomach. Several lipases may act at that level :

- an enzyme secreted by the serous glands of the tongue (Hamosh and Scow, 1973 ; Hamosh ef al., 1975) and having an optimum pH activity between 4.5 and 5.4. This enzyme preferentially hydrolyzes the ester bond at position 3 of the triglyceride molecule by forming 1.2-diglycerides (Paltauf, Esfandi and Holasek, 1974) without recourse to bile salt activation ;

- an enzyme present in homogenates of gastric mucosa and secreted in the stomach lumen during a lipid meal. This enzyme would hydrolyze the short and mediumchain triglycerides. There is some doubt as to its true activity on the stomach contents since the lipase activity at that level could be of lingual origin.

A lipase in primate milk would not be denatured at acid $\mathrm{pH}$ in the stomach and, on reaching the infant duodenum, could act after it has been activated by bile salts (Hernell and Olivecrona, 1974).

* Older studies have been reported in an article by Clément published in 1976 ; recent reviews on certain aspects of the digestion and absorption of lipids have appeared (Strauss, 1968 ; Hofmann and Mekhjian, 1973 ; Borgström, 1974 ; Brindley, 1974 ; Simmonds, 1974 ; Johnston, 1977). 
Intestinal stage. - Triglyceride lipolysis is higher in the small intestine than in the stomach due to the action of pancreatic lipase and bile. In 1856 Claude Bernard showed that the simultaneous presence of these two secretions in the small intestine was a prerequisite to chyliferous vessel lactescence after fat intake.

The mode of pancreatic lipase action has been elucidated by Desnuelle and his team (Desnuelle, Naudet and Rozier, 1947, 1948 ; Desnuelle, Naudet and Constantin, 1951 ; Savary and Desnuelle, 1956), Mattson and his collaborators (Mattson et al., 1952 ; Mattson and Beck, 1955, 1956 ; Mattson and Volpenhein, 1968), and Borgström (1952a, b; 1953a, b; 1954a, b).

This enzyme acts on triglycerides at the oil-water interface of the intraluminary lipid particles; when the triglycerides contain long-chain fatty acids, it releases those at positions 1 and 3 to first give 1.2 or 2.3-diglycerides, then 2-monoglycerides. Two fatty acids per molecule of hydrolyzed triglycerides are thus released (fig. 1).

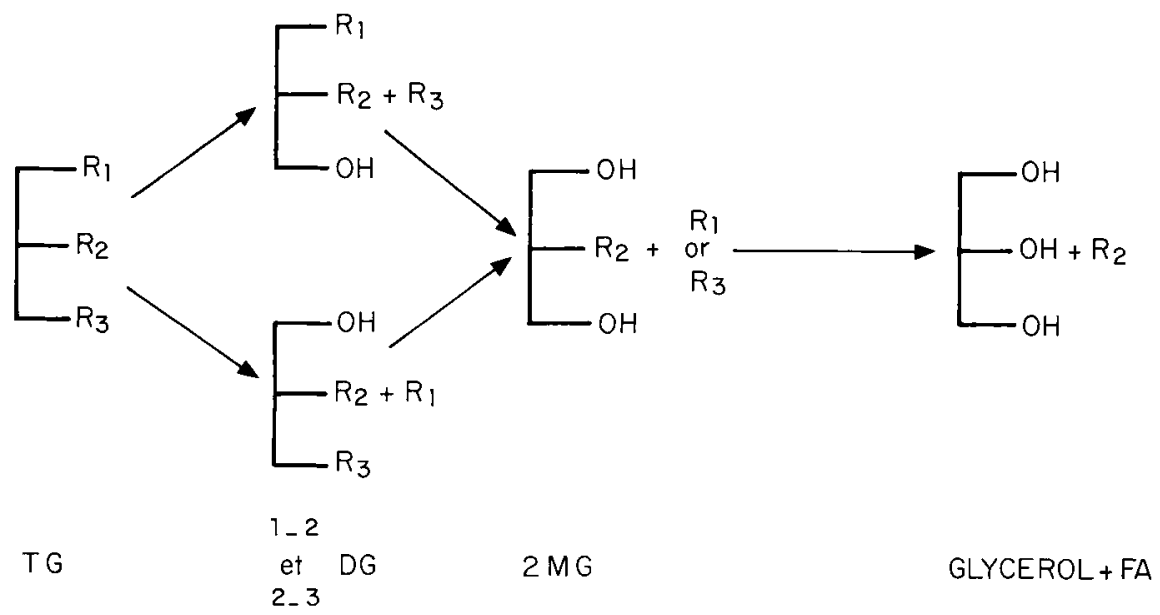

FIG. 1. - Hydrolysis of long fotty acid triglycerides by pancreatic lipase.

Abbreviations : $T G=$ triglycerides, $D G=$ diglycerides, $M G=$ monoglycerides, $F A=$ fatty acids.

The enzyme shows no preference for either position 1 or 3 (Tattrie, Bailey and Kates, 1958). 2-monoglycerides may be hydrolyzed into fatty acid and glycerol ; this hydrolysis is slower and concerns only 25 to 50 p. 100 of the 2-monoglycerides (Reiser et al., 1952 ; Borgström et al., 1957 ; Blomstrand, Borgström and Dahiback, 1959 ; Buel and Reiser, 1959 ; Morehouse ef al., 1956) ; the released glycerol thus follows the portal route and is hardly reused for glycerolipid synthesis in the intestinal mucosa.

The rate of long-chain (12 to $18 \mathrm{C}$ atoms having 0,1 or 2 double-bonds) fatty acid hydrolysis is similar, but when the triglycerides are composed of fatty acids of $10 \mathrm{C}$ atoms or less, those fatty acids are released quicker than the long-chain ones, whatever their position in the original triglyceride molecule (Entressangles et al., 1961 ; Clément, Clément and Bezard, 1962). Lipase activity according to the trigly- 
ceride fatty acid structure (double-bond localization, branched polyenoic acids, chain longer than $18 \mathrm{C}$ ) has been studied by Brockerhoff (1970).

The properties of pancreatic lipase originally determined, particularly that of bile salt-dependent activation, have been revised since a pancreatic colipase was demonstrated by Morgan, Barrowman and Borgström (1969) and Maylie ef al. (1971). The action of the lipase-colipase system has been explained by Chapus ef al. (1975) : bile salts, at a higher concentration than the critical micellar concentration usually found in the bile and the infestinal lumen, inhibit lipase by preventing its contact with the substrate (triglycerides) when colipase is absent. On the contrary, if colipase is associated with lipase, this enzymatic system may be adsorbed at the triglyceridewater inferface, and the lipase can then act. When bile salts are absent, the lipase would be quickly denatured (Borgström, 1977). Some recent studies (Lairon ef al., 1978) indicate that phospholipids and bile cholesterol might transport the lipasecolipase association to the triglyceride-water interface.

Intestinal juice also has lipasic action on long-chain triglycerides.

All these reactions or properties, which have been demonstrated mostly in in vitro experiments, have been confirmed with in vivo studies. Thus, after triglyceride intake, a mixture composed of triglycerides, 1.2 and 2.3-diglycerides, 2-monoglycerides and free fatty acids is found in the small intestine lumen. However, due to isomerization, 1-monoglycerides (15 to $20 \mathrm{p}$. 100 of the total monoglycerides) and small amounts of 1.3-diglycerides are also found at that level. Moreover, fatty acids are exchanged between those located at positions 1 and 3 of the triglyceride molecules and the intraluminal free fatty acids; these exchanges are catalyzed by the lipase according to a reverse lipolytic reaction (Ahrens and Borgström, 1956 ; Reiser and Fu, 1966).

\section{B. - Physico-chemical state of intraluminary lipids.}

The fat must be well dispersed if the intraluminal lipid particles are to cross the intestinal epithelium. According to Hofmann and Borgström (1963), this process occurs as if there were two phases in the intestinal lumen (fig. 2) : an «emulsion 》 phase of tiny oil droplets suspended in the aqueous medium and a micellar phase (originally present in the intestine). The emulsion would be previously formed in the stomach due to stirring movements and continued in the intestine owing to the defergent action of bile salts which decrease particle size from 50000 to $2000 \AA$, thus augmenting the oil-water interface surface. This emulsion would contact the micellar phase which is composed of bile micelles (bile salts, phospholipids, cholesterol) with a 20 to $30 \AA$ diameter. Bile salts and pancreatic enzymes are present at the oil-water inferface. Triglyceride lipolysis begins; the diglycerides and the non-ionized fatty acids, practically insoluble in the bile salts, remain in the triglyceride emulsion, while the monoglycerides and the ionized fatty acids are solubilized in the bile micelles to form mixed micelles which have a larger diameter ( 30 to $50 \AA$ ). An equilibrium is established between the two phases at the onset of digestion in the proximal intestine.

Agreement has not yet been reached as to the form in which lipids are absorbed. According to some authors, absorption is molecular ; in all cases, this type of absorption involves short and medium-chain fatty acids and medium-chain monoglycerides 


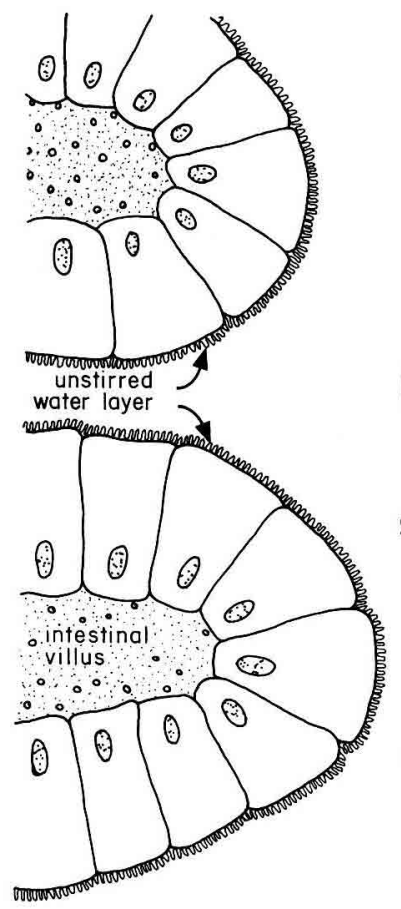

INTESTINAL

LUMEN

stirred zone
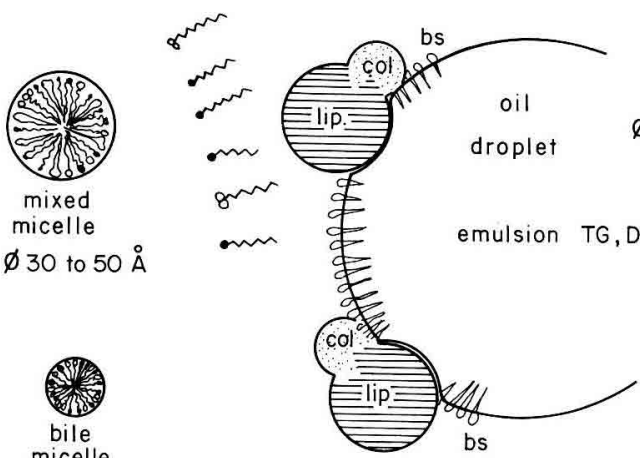

micelle

$\emptyset 20$ to $30 \AA$

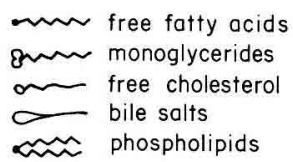

FIG. 2. - Figure showing the physico-chemical stale of intraluminary lipids in the duodenum. The figure showing adsorption of the lipase-colipase association at the oil-water interface is from: Chapus ef al. (1975). Abbreviations : $F C h=$ free cholesterol, $\mathrm{ChE}=$ cholesterol esters. $\mathrm{PL}=$ phospholipids, FFA $=$ free fatty acids, bs $=$ bile salts, see fig. 1 for others.

which have enough polarity to cross the intestinal epithelium without belonging to micelles; it has been shown that they can be absorbed when bile salts are absent. Most researchers believe that absorption occurs by the diffusion of intact micelles across the enterocyte membrane, but they have not yet determined how far the micelle penetrates into the enterocyte. In fact, mixed micelles would not be taken up directly through the enterocyte membrane, but would have to overcome the resistance of the unstirred layer first (Wilson and Dietschy, 1972 ; Westergaard and Dietschy, 1976). This layer has no morphological basis; it is neither the mucus nor the glycocalyx. Although its existence has not been demonstrated, it would correspond to the need of biophysicians to explain the enterocyte uptake of intraluminal lipids. They visualize it as a layer of water between 50 and $400 \mu \mathrm{m}$ thick adjacent to the brush border. It is not known whether there would be a single layer of water or several in which particle stirring would increase from the periphery of the intestinal lumen to its center.

When the concentration of lipolytic products (monoglycerides, free fatty acids) increases in the stirred part of the intestinal lumen, the flux of material increases in the unstirred layer, and the plasmic membrane of the enterocyte may be penetrated. Lipid molecules would first be transferred from the aqueous side of the cell membrane interface, then diffused through the structured lipid membrane and transited towards 
the aqueous cytoplasm. Diffusion would be maximal, if the solution was saturated at the interface, but this cannot occur due to unstirred layer resistance (Simmonds, 1976).

The micelle would not be intact after crossing the plasmic membrane of the microvilli because that layer would offer too much resistance to the bile salts; this would explain their later absorption in the ileum. The micelles would certainly be demolished since it has been shown elsewhere that other micellar components such as bile phospholipids and cholesterol, are absorbed before they arrive in the ileum (phospholipids : Ulrich, Boucrot and Clément, 1974 ; cholesterol : Lutton and Brot-Laroche, 1979).

Lipid absorption would take place in the tips of the microvilli and not in the crypts, that is, where the unstirred layer would be thinnest $(50 \mu \mathrm{m})$.

Short and medium-chain fatty acids would easily cross this unstirred layer (Sallée and Dietschy, 1973).

\section{Absorption}

As gastric emptying occurs intermittingly, small quantities of lipids reach the duodenum. Pancreatic lipase is usually secreted abundantly in the duodenum, so that the monoglycerides and free fatty acids (products of triglyceride hydrolysis) are quickly absorbed in the proximal small intestine. However, when a greater amount of lipids is ingested, a larger intestinal mucosa surface is used and the ileum can absorb (Favarger, 1958, 1960 ; Bennett, 1964 ; Vodovar ef al., 1965). It should be noted that the enzymes needed for triglyceride resynthesis are usually inactive at that level, but acquire this synthesizing ability (Hoving and Valkena, 1969 ; Rodgers and Bochenek, 1970). The absorption coefficient of the usual dietary fats is high (95 p. 100). The forms in which lipids, resulting from triglyceride hydrolysis, are absorbed are mostly 2-monoglycerides and free fatty acids. These facts have been demonstrated by experiments isolating the intestinal loop in situ or by analyses of lymph triglycerides. It has thus been shown that the fatty acid located at position 2 of dietary triglycerides occurs again in high amounts in that position in lymph triglycerides (Savary, Constantin and Desnuelle, 1961 ; Mattson and Volpenhein, 1962, 1964 ; Clément and Paris, 1964 ; Paris and Clément, 1968).

It is now admitted that intact triglycerides cannot be absorbed.

\section{A. - Biochemical processes in the enterocyte.}

A monoglyceride-lipase in the enterocyte (Di Nella, Meng and Park, 1959 ; Senior and Isselbacher, 1963) hydrolyzes the monoglyceride-ester bond. This enzyme would be especially active :

- when there is an excess of monoglycerides and a lack of free fatty acids to acylate the former ;

- in the case of short and medium-chain monoglycerides;

- when the fatty acid configuration is inadequate (e. g. trans-fatty acids, branched fatty acids).

Most fatty acids (free or esterified as monoglycerides) which are taken up by the intestinal mucosa then appear in the chylomicrons in the form of triglycerides, except 
for those which have a carbon chain shorter than $12 \mathrm{C}$. In fact, the free form of these fatty acids is vehiculed towards the liver (fig. 3) by portal blood albumins in amounts which increase in proportion to the shortness of their chains. According to Bloom, Chaikoff and Reinhardt (1951), only 10 p. 100 of the decanoic acid (10 C) ingested appears in the lymph in the form of triglycerides, while when lauric (12 C) and myristic $(14 \mathrm{C}$ ) acids are ingested, 50 and 60 p. 100, respectively, are found. The values for fatty acids with more than $14 \mathrm{C}$ vary between 70 and $90 \mathrm{p} .100$. This chyloportal fatty acid distribution according to chain length has been confirmed and elucidated (Borgström, 1955 ; Fernandes, Van de Kamer and Weijers, 1955 ; Blomstrand, 1955 ; Blomstrand and Ahrens, 1958 ; Blomstrand, Thorn and Ahrens, 1958 ; Clément ef al., 1963 ; Gottenbos and Thomasson, 1963).

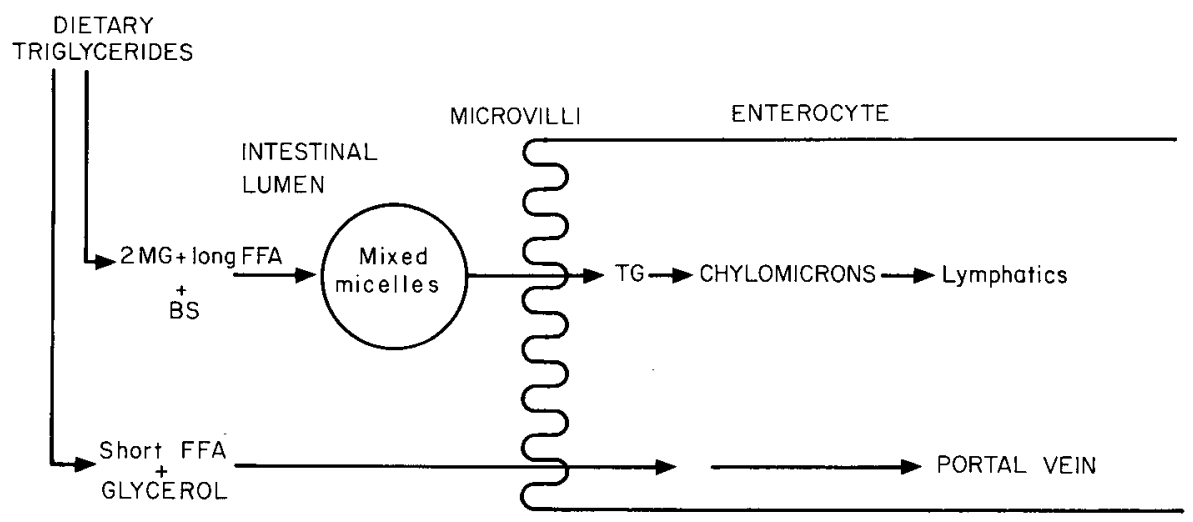

FIG. 3. - Chyloportal distribution of fotty acids according to chain length. Abbreviations : see figs. 1 and 2.

Triglyceride synthesis in the enterocyte.

This synthesis is very active and cannot be considered as a reverse reaction of pancreatic lipolysis.

While lipid transit across the plasmic membrane demands no energetic effort (Strauss, 1968), fatty acids in order to esterify alcohol from glycerol must be previously activated (Kornberg and Pricer, 1953) to form acyl-CoA, a reaction catalyzed by an acyl-CoA ligase in the presence of ATP and $\mathrm{Mg}^{++}$ions :

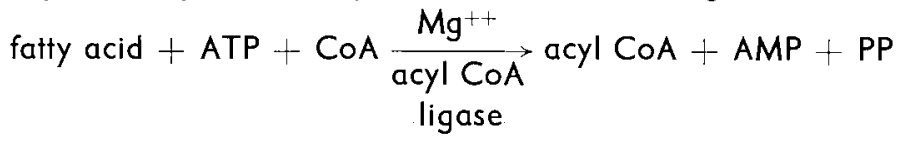

Triglyceride synthesis is carried out :

- with acyl CoA which esterifies the Sn glycerol-3 phosphate in the way described by Weiss and Kennedy (1956) and the data reported by Dawson and Isselbacher (1960), Johnston and Bearden (1960a, b) and Brindley and Hübscher (1965) :

acyl CoA + Sn-glycerol 3-P $\rightarrow$ lysophosphatidic acid + CoA

acyl CoA + lysophosphatidic acid $\rightarrow$ phosphatidic acid + CoA 
phosphatidic acid 1.2 diglyceride $+P$

phosphatidate phosphohydrolase

1-2 diglyceride + acyl CoA $\longrightarrow$ triglyceride + CoA diglyceride acyltransferase
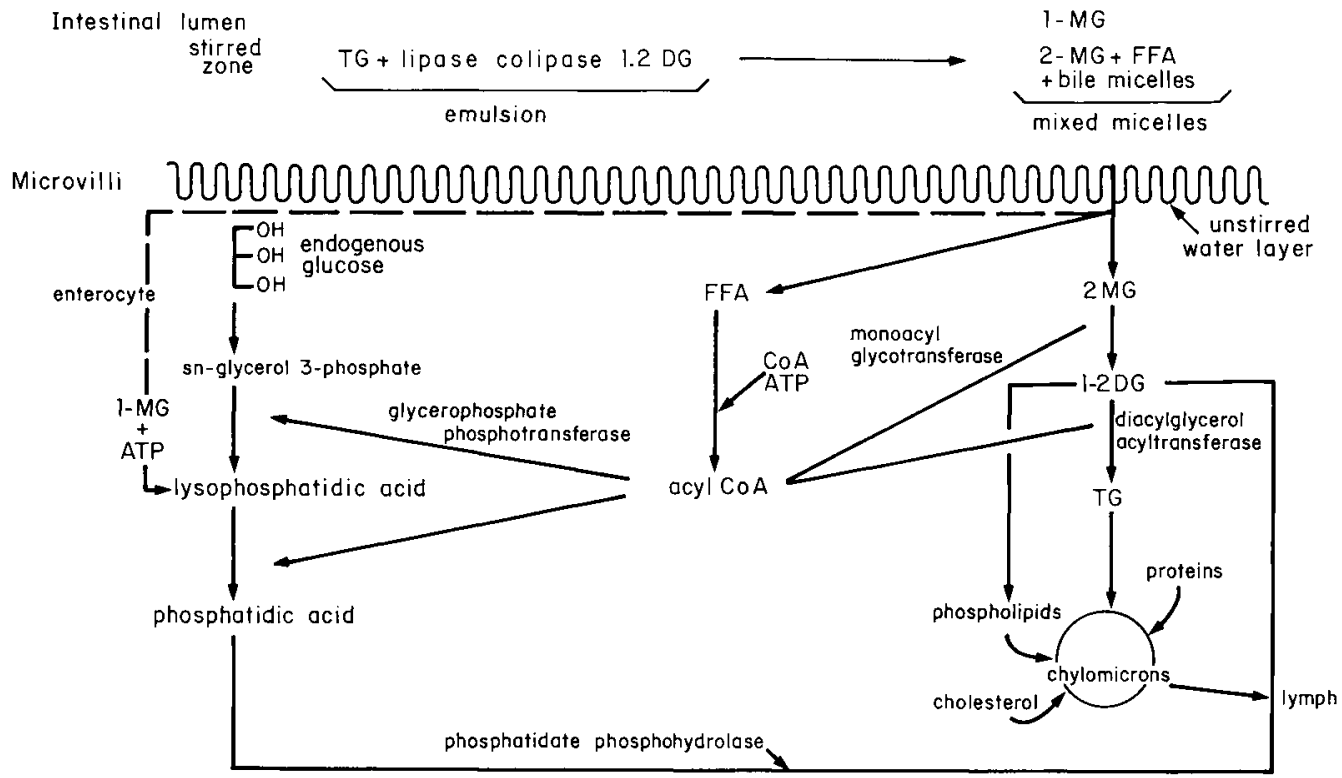

FIG. 4. - De novo synthesis of enterocyie triglycerides.

The formation of lysophosphatidic and phosphatidic acids by direct acylation of phosphate dihydroxyacetone, demonstrated in the liver by Hajra and Agranoff $(1968 a, b)$, may also occur in the enterocyte according to RAO, Sorrels and Reiser (1970), but the importance of this route remains to be determined in vivo.

The computations of Kern and Borgström (1965) and Paris and Clément (1965) indicate that 14 p. 100 of the triglycerides in the intestinal mucosa would be synthesized in the above way.

- Triglyceride synthesis would also be corried out with monoglycerides by direct acylation (Clark and Hübscher, 1960) :

$$
\begin{aligned}
& \text { monoglyceride }+ \text { acyl } \mathrm{CoA} \longrightarrow \text { diglyceride }+\mathrm{CoA} \\
& \text { monoglyceride acyltransferase }
\end{aligned}
$$

diglyceride + acyl $\mathrm{CoA} \longrightarrow \longrightarrow$ triglyceride $+\mathrm{CoA}$

diglyceride acyltransferase

The enzymes which catalyze the acylation of both substrates are different.

Many studies have confirmed the existence of these processes (Senior and isselbacher, 1961a, b ; Johnston and Brown, 1962 ; Brown and Johnston, 1963 ; Johnston, Rao and Reistad, 1965 ; Ailhaud, Samuel and Desnuelle, 1963).

According to Paris and Clément $(1965,1969)$ this type of synthesis would be especially important for 2-monoglycerides. On the contrary, 1-monoglycerides would be 
phosphorylated directly, thus forming lysophosphatic acids, and the processes would continue as shown above. This has been recently confirmed by Breckenridge and Kuksis $(1975 a, b)$.

This triglyceride synthesis using two substrates occurs in the smooth endoplasmic reticulum (Brindley and Hübscher, 1965 ; Schiller, David and Johnston, 1970) where all the necessary enzymes are found.

The long-chain fatty acids would be transferred from the microvilli to the smooth reticulum of the enterocyte because they are bound to a cytosolic protein (Ockner ef al., 1972), abundant in the proximal small intestine and especially in the cristae of the villi (as compared to the crypts). This protein has a higher affinity for unsaturated than saturated fatty acids and does not bind short or medium-chain fatty acids (Ockner, Pittman and Yager, 1972). It would be identical to the Z-protein of Levi, Gatmaitan and Arias (1969) and O'Doherty and Kuksis (1975).

According to various authors, triglyceride or phospholipid synthesis in the enterocyte might be regulated by the amounts of monoglycerides present; if these amounts

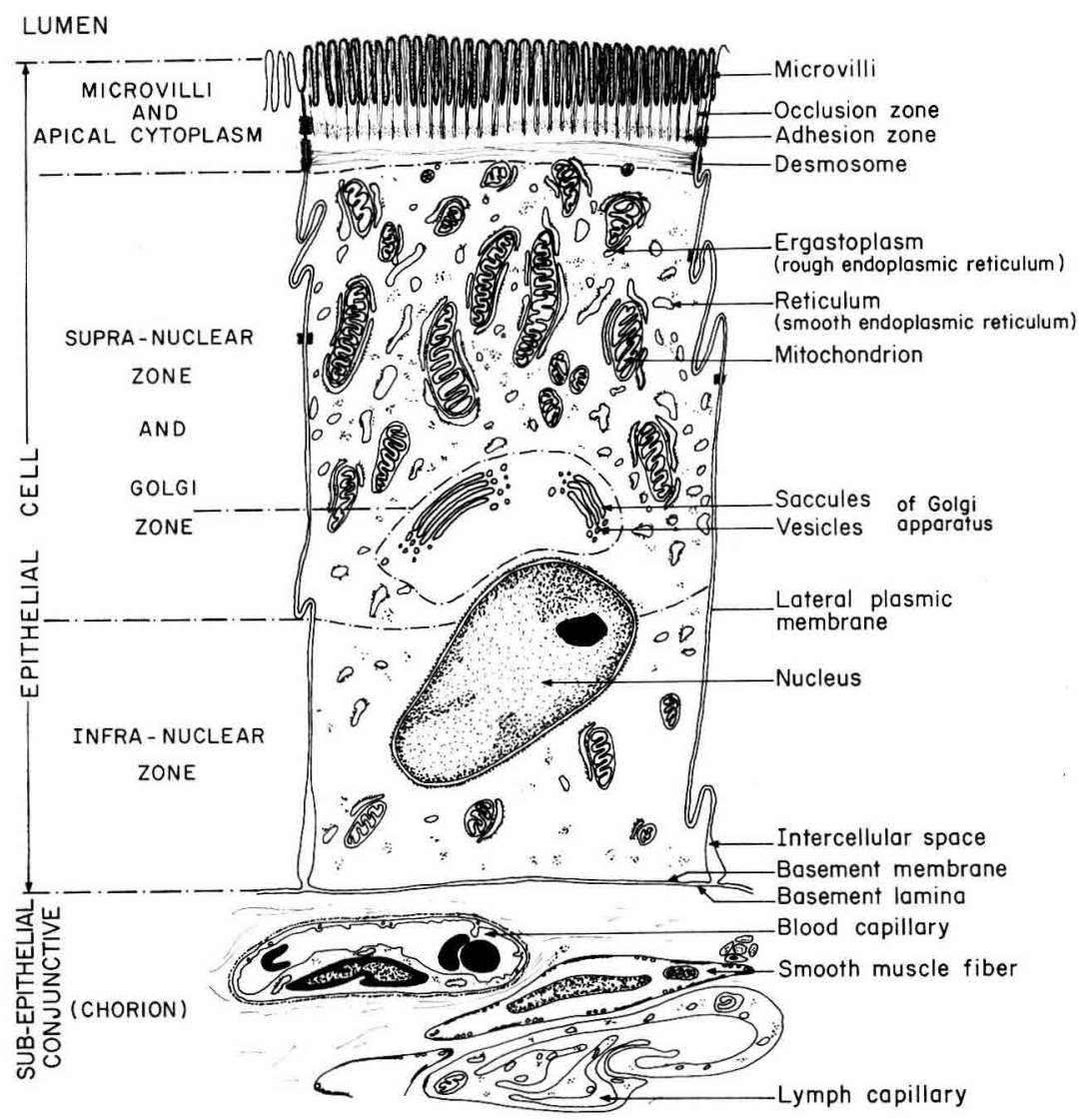

FIG. 5. - Rat enterocyte (from Carlier, 1973). Size of cells from the proximal small intestine : 25 to $39 \mu \mathrm{m} \times 4.5$ to $8 \mu \mathrm{m}$. Size of microvilli : 0.8 to $1.5 \mu \mathrm{m} \times 0.08$ to $0.1 \mu \mathrm{m}$. 
are considerable, endogenous glycerophosphate acylation would be inhibited and triglyceride synthesis enhanced. Breckenridge and Kuksis $(1975 a, b)$ do not agree with this scenario ; they show that it is the degree of unsaturation of the diglycerides formed which regulates further synthesis of triglycerides or phospholipids, and not their origin, monoglycerides or phosphatidic acids (see synthesis above). Several authors support this last conclusion (Hülsmann and Kurpershogk-Davidov, 1976 ; Shiau, Long and Weiss, 1978).

Mansbach (1973) and Johnston (1977) showed that the monoglyceride acyltransferase of microsomes isolated in villous crypt cells is lower than that in the microsomes of the cells of tips. Johnston (1977) concluded that the triglycerides would be formed mainly in the tips from monoglycerides, while the phospholipids would be synthesized in the crypts via phosphatidic acids. Thus, the synthesis of triglycerides from monoglycerides would be induced by the migration and differentiation of intestinal cells, formed in the crypts then migrating to the cristae where they are differentiated.

Some more work remains to be done on the problem of regulation of the synthesis of triglycerides and phospholipids in the enterocyte.

\section{B. - Morphological aspects of intestinal lipid absorption (figs. 5, 6).}

During fat absorption, the enterocytes accumulate lipid droplets of various sizes ; these droplets first appear in the median apical zone of the cell and group together near the nucleus to form large granules which occupy all the zone between the nucleus and the apical pole. Lipids cannot be demonstrated by staining the microvilli and the apical cytoplasm (fig. 6A).

The theory of pinocytotic absorption (Palay and Karlin, 1959) postulates that intraluminary lipid particles enter the absorptive cell by invagination of the membrane in the intermicrovillous spaces. This hypothesis has been abandoned due to Sjöstrand's (1963) objections since he favors the theory that lipids would be absorbed by molecular or micellar diffusion.

Some studies using autoradiography with electron microscopy (Strauss and lto, 1965 ; Cardell, Badenhausen and Porter, 1967 ; Dermer, 1968 ; Carlier, Clément and Noirot-Thimothée, 1969 ; Carlier, 1971, 1973) have made it possible to determine lipids at some levels (microvilli, subjacent apical cytoplasm) where they could never have been detected by staining (fig. 6A). These studies also demonstrated that the labelled lipid droplets are bound to the smooth reticulum membranes and fuse in the

FIG. 6A. - Apical zone of absorptive cells of the rat infestinal epithelium $20 \mathrm{~min}$ after intake of $1.5 \mathrm{~m} /$ of corn oil. 2 p. $100 \mathrm{OsO}_{4}$ fixation, complete dehydration, Epon embedding, OTO contrast. $\times 18600$. Undefectable lipids in the zone of the microvilli ( $\mathrm{mv}$ ) and apical cytoplasm (ca). The numerous highly contrasted lipid particles in the vesicles of the endoplasmic reticulum are not coalesced.

FIG. 6B. - Golgi zone of the rat intestinal epithelium cell $2 \mathrm{~h}$ after intake of a $20 \mathrm{p} .100$ peanut oil diet. Double fixation by glutaraldehyde, then $\mathrm{OsO}_{4}$, complete hydration, Epon embedding, contrast by uranyl acetate and lead citrate. $X 24,500$. In the supranuclear zone are seen : well developed Golgi bodies $(g)$; Golgi vesicles $(\rightarrow$ ) filled with well-individualized lipoprotein particles. Exocytosis ( ) is visible in the lateral plasmic membrane ; $n=$ nucleus (From Bernard ef al., 1979b). 

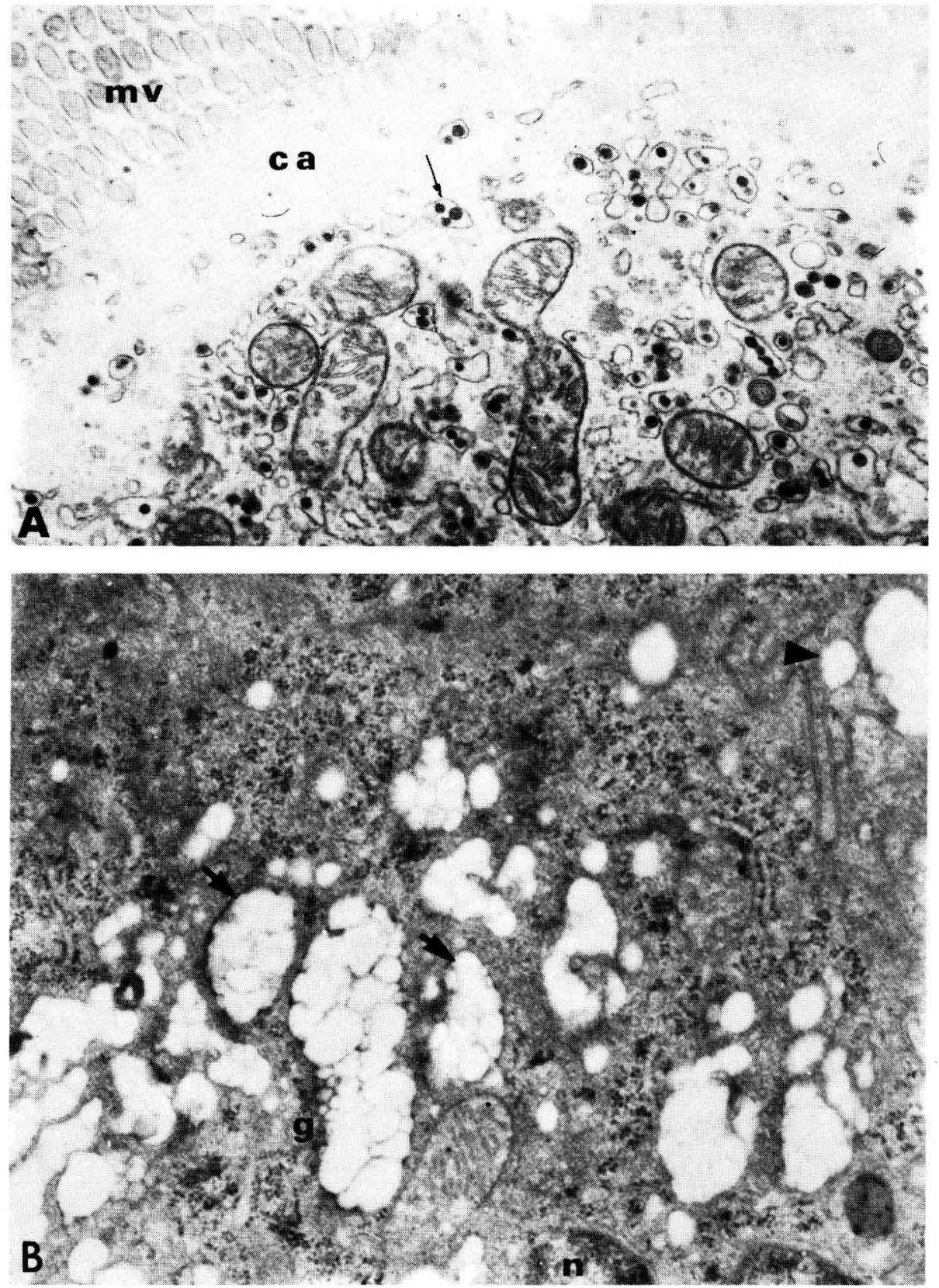
Golgi apparatus where they are of the same size as those in the lymphatic chylomicrons.

Lipids have been sometimes evidenced in the rough plasmic reticulum, thus confirming the conclusions of Cardell, Baden-Hausen and Porter (1967) that the rough endoplasmic reticulum (only detectable at an early stage) evolves into smooth endoplasmic reticulum which appears after intake of a fatty meal. The rough endoplasmic reticulum would be the site of protein and lipid syntheses by the glycerophosphate route (Higgins and Barnett, 1971). These newly synthesized proteins and phospholipids should (it has not yet been demonstrated) be transferred in the Golgi apparatus to the surface of triglyceride particles, thus stabilizing the hydrophobic center of the chylomicrons in their aqueous medium (Mahley ef al., 1971). At that level, sugars would be added also (Redgrave, 1971 ; Schachter and Roden, 1973) to the prechylomicrons due to the glycosyltransferases present (Kessler, Narcessian and Mandlin, 1975). The Golgi apparatus is limited to the supranuclear zone (fig. 6B).

During absorption, the intercellular spaces dilate and the chylomicrons fuse with the plasmic membrane, reaching those spaces by a reversed type of pinocytosis or exocytosis. Friedman and Cardell (1972) showed morphologically that this exocytosis occurred by a fusion of the Golgi vesicles with the lateral plasmic membrane; Carlier and Bezard (1975) confirmed this in an autoradiographic study.

The chylomicrons first appear in the intercellular space, then in the lamina propria and finally in the lymphatics.

As filaments and microtubules are associated with elements of the endoplasmic reticulum and the Golgi apparatus, Glickman (1976) believes that the microtubules may play a role in transferring chylomicrons from the Golgi apparatus to the sites of exocytosis.

The morphology of the intestinal cells varies after the intake of a fatty meal : the Golgi apparatus of some cells is filled with chylomicrons, while others would be in the final phase of absorption (Sabesin, 1976 ; Bernard ef al., 1979b).

\section{C. - Transport of dietary lipids by lymph lipoproteins.}

The triglycerides resynthesized in the enterocytes are vehiculed in the chyle by chylomicrons $(\mathrm{d}=0.96)$ and very low-density lipoproteins (VLDL) $(d \leqslant 1.0006)$ (Ockner, Hughes and Isselbacher, 1969a, b; Ockner and Jones, 1970 ; Boquillon, Paris and Clément, 1972). These lipid particles are spheres with a diameter of 0.05 to $0.75 \mu \mathrm{m}$ (3 $\mu \mathrm{m}$ is exceptional) (Zilversmit, 1965 ; Blanchette-Mackie and Scow, 1973 ; Boquillon, Carlier and Clément, 1974).

The chylomicron Sf (= floating unit = Svedberg unit) is $>400$ and that of the VLDL ranges between 20 and 400 .

The chemical composition of chylomicrons includes 85 to 90 p. 100 of triglycerides (mixed with small amounts of monoglycerides and diglycerides, cholesterol esters, free fatty acids) localized at the center, 8 to 13 p. 100 of phospholipids, 2 to 3.4 p. 100 of free cholesterol and 0.5 to 2 p. 100 of protein in surface. These surface substances, which are more polar than those of the center, play an important role in maintaining particle structure (Zilversmit, 1965, 1968). The composition and structure of the VLDL are similar to those of the chylomicrons but the VLDL are richer in proteins, phospholipids and cholesterol and poorer in triglycerides. 
1. - The protein moiety. Although the protein content of these particles is low, the presence of protein is imperative for their formation and transport.

It has been known for some time that the mucosa can synthesize some proteins which are later found in the lymph (Rodbell and Fredrickson, 1959 ; Rodbell, Fredrickson and Ono, 1959 ; Isselbacher and Budz, 1963). Since then, details have appeared on the composition of some characteristic proteins (apoproteins) of chylomicrons and of VLDL in the lymphatics. In rat chylomicrons, 7 p. 100 of Apo A, 20 p. 100 of apo B, 70 p. 100 of apo $C$ and 3 p. 100 of apo $E$ have been reported. A recent study in humans by Green ef al. (1979) indicates the apoprotein composition of these particles.

Apo $A$ and $B$ are synthesized in the enterocyte (Roheim, Gidez and Eder, 1966 ; Havel et al., 1970 ; Windmueller ef al., 1970 ; Kostner and Holasek, 1972 ; Windmueller, Herbert and Levy, 1973 ; Glickman and Green, 1977 ; Wu and Windmueller, 1978 ; Holt, Wu and Bennett-Clark, 1979), while apo C, which is preponderant, would be supplied by the blood irrigating the intestinal mucosa with high-density lipoproteins of hepatic origin (Windmueller, Herbert and Levy, 1973 ; Havel, Kane and Kashiap, 1973) ; apo E would also be synthesized by the liver (Marsh, 1976 ; Felker ef al., 1975).

Apo B plays a major role in chylomicron formation in humans presenting an abetalipoproteinemia : there is no intestinal absorption of long-chain fatty acids, no chylomicron formation in the intestinal mucosa and, thus, no lymph transport of lipids. Only short and medium-chain fatty acids can be absorbed directly, reaching the liver by the portal blood. When the rat is given drugs such as cycloheximide or its derivatives, which inhibit protein synthesis, the transfer of phospholipids and proteins of the rough endoplasmic reticulum towards the Golgi apparatus does not occur (Levy, Fredrickson and Lester, 1966 ; Vodovar, Massicard and Flanzy, 1968) or is disturbed (Bernard et al., 1979a) ; lipid particles then accumulate in the enterocyte. In these conditions, some very large chylomicrons are observed in the lymph (Glickman, Kirsch and Isselbacher, 1972).

2. - The lipid moiety. Fatty acids belonging to lymph triglycerides are mainly derived from dietary fats ; however, some endogenous fatty acids may also enter into their composition (Bragdon and Karmen, 1960 ; Kayden ef al., 1960 ; Kayden, Karmen and Dumont, 1963 ; Boucrot and Clément, 1965). When dietary fats contain short and medium-chain fatty acids, and these fatty acids mainly use the portal route, the triglyceride composition of lymph chylomicrons does not reflect that of the ingested triglycerides (Clément et al., 1963 ; Gottenbos and Thomasson, 1963 ; Courel and Clément, 1964).

This non-dietary fatty acid dilution of the exogenous fatty acids of lymph triglycerides appears particularly high at the beginning and the end of absorption (Kayden et al., 1960 ; Kayden, Karmen and Dumont, 1963 ; Courel and Clément, 1964 ; Verdino, Blank and Privett, 1965) and is evidently very low at maximal absorption (6 to $8 \mathrm{~h}$ after a meal in humans ; 2 to $3 \mathrm{~h}$ after in rats).

The quantity of endogenous fatty acids found daily in chylomicron triglycerides is rather constant (about $150 \mathrm{mg}$ for a $200 \mathrm{~g}$ rat : Savary and Constantin, 1967 ; Boucrot and Clément, 1969) but according to the latter authors, it would not be equally distri- 
buted in time, being maximal at exogenous lipid absorption. Moreover, the quantities of ingested lipids and the number of meals would have no effect on its value.

Part of the endogenous fatty acids found in the lymph triglycerides are derived from the intestinal lumen (Burr, McPherson and Tidwell, 1960 ; Di Costanzo and Clément, 1965a, b ; Baxter, 1966). The intraluminal endogenous lipids undergo the same processes as dietary lipids. These endogenous lipids originate mostly from those present in the digestive secretions, mainly the bile $(3 \mathrm{mg} / \mathrm{h} / \mathrm{rat} ; 0.5$ to $5 \mathrm{~g} / 24 \mathrm{~h} / \mathrm{man})$ (Ockner, Hughes and Isselbacher, 1969a ; Baxter, 1966 ; Simmonds, Redgrave and Willix, 1968) and also in desquamated cells according to Cotton (1972) studying the rat $(1.12 \mathrm{mg} / 30 \mathrm{~min}$ ) and to Croft and Cotton (1973) studying humans (12 to $30 \mathrm{~g} / \mathrm{day}$ ). Some endogenous fatty acids constituting chylomicron triglycerides could also be derived from blood lipids irrigating the intestinal mucosa (Burr, McPherson and Tidwell, 1960 ; Baxter, 1966 ; Boucrot and Clément, 1969 ; Gangl and Ockner, 1975) or could be synthesized at that level (Coniglio and Cate, 1958 ; Ganguly, 1960 ; Franks, Riley and Isselbacher, 1966). This synthesis is always low and constant whatever the nutritional state (Zakim and $\mathrm{Ho}, 1970$ ) and is more intense in the crypts than in the cristae of the villi (Dietschy, 1968).

The fatty acid carbon-chain may also be transformed in the enterocyte by elongation, shortening and double-bond formation (Boucrot and Clément, 1965b; Reeve and Franks, 1968 ; Bickerstaffe and Annison, 1969). Moreover, fatty acids taken up by the intestinal mucosa may undergo $\beta$-oxidation (Porte and Entenman, 1965 ; Metais, Bach and Warter, 1967) and, according to the latter authors, the short and mediumchain fatty acids would be oxidated preferentially. Gangl and Ockner (1975) report that plasma long-chain fatty acids would be oxidated in the enterocyte rather than exogenous fatty acids.

The fatty acids constituting chylomicron phospholipids are mostly of endogenous origin ; their composition is thus little affected by the type of fatty acids ingested. However, when double-labelled phospholipids (glycerol and fatty acids at position 1 or 2) are ingested, considerable amounts of labelled fatty acids in the triglycerides and the phospholipids are taken up by the chylomicrons (Blomstrand, 1954); only the labelling of glycerol and of the fatty acid originally located at position 1 remains, i. e. there has been absorption of 1-monoglycerophosphatide, then acylation of position 2 by an endogenous fatty acid (Scow, Stein and Stein, 1967 ; Nilsson, 1968 ; Arvidson and Nilsson, 1972).

Chylomicron cholesterol has several origins : the diet (Swell et al., 1955 ; Borgström, Lindhe and Wlodawer, 1958 ; Clément, Clément and Brasseul, 1959 ; Clément and Mead, 1959 ; Chevallier and Vyas, 1963), the bile, the blood irrigating the intestinal mucosa and especially enterocyte synthesis (Dietschy and Siperstein, 1965 ; Chevallier and Lutton, 1972, 1973).

Journées Ingestion-Digestion-Absorption de l'Association française de Nutrition, Paris, $15-16$ novembre 1979.

Résumé. Les triglycérides subissent une digestion intense dans la lumière de l'intestin grêle ; étant insolubles dans les milieux aqueux, ils doivent être transformés en substances plus polaires pour franchir l'épithélium intestinal. Cette transformation s'effectue grâce à la lipase pancréatique ; celle-ci, à condition qu'elle soit associée à la colipase, peul agir à 
l'interphase huile - eau ; elle libère alors les acides gras situés en positions 1 ef 3 des triglycérides pour former des 2-monoglycérides; elle peut hydrolyser ces derniers, mais cette hydrolyse totale n'intéresse que 25 à 50 p. 100 d'entre eux.

Les acides gras libres et les 2 -monoglycérides issus de la lipolyse se dissolvent dans les micelles biliaires pour former des micelles mixtes ; celles-ci ont la possibilité de traverser par diffusion la membrane plasmique de l'entérocyłe après avoir vaincu la résistance de la «couche d'eau non agitée » qui recouvre la bordure en brosse.

L'absorption intestinale est importante dans le duodénum et le jéjunum, en particulier celle des monoglycérides serait plus élevée dans les crêtes que dans les cryptes des villosités.

La resynthèse des triglycérides a lieu dans le réticulum endoplasmique lisse de l'entérocyte :

1) à partir des acides gras libres par acylation de glycérophosphate endogène, via les acides phosphatidiques ef les diglycérides (le glycérol libéré des triglycérides ingérés est peu réutilisé) ;

2) à partir des 2-monoglycérides par estérification directe des fonctions «alcool»;

3) à partir des 1-monoglycérides par phosphorylation via les acides lysophosphatidiques. Les acides gras qui estérifient ces substrats doivent auparavant être activés sous forme d'acyl-CoA.

Les triglycérides resynthétisés migrent vers l'appareil de Golgi où sont formés les chylomicrons par addition de phospholipides, de protéines - synthétisés au préalable dans le réticulum endoplasmique granuleux - de cholestérol et de sucres.

Les chylomicrons quittent l'entérocyte par exocytose par la membrane plasmique latérale vers les espaces intercellulaires; puis, après passage dans la lamina propria, ils empruntent les lymphatiques.

Les triglycérides resynthétisés sont en fait transportés dans la lymphe par les chylomicrons et les lipoprotéines de très basse densité. Ce sont des particules de 0,05 à $0,75 \mu \mathrm{m}$, les triglycérides étant localisés au centre, phospholipides, cholestérol libre et protéines en surface. Les protéines des chylomicrons ( 0,5 à 2 p. 100 en masse) sont importantes pour leur formation et leur transport dans la lymphe. On distingue parmi elles, l'apo A (7 p. 100), l'apo B (20 p. 100), l'apo C (70 p. 100) et l'apo $E(3$ p. 100) ; les deux premières sont synthétisées dans l'entérocyte, l'apo $C$ serait apportée par les lipoprotéines sériques de haute densité.

Dans les chylomicrons, les phospholipides ont surtout une origine endogène, le cholestérol a de multiples sources (alimentation, sang, secrétions digestives, synthèse dans l'entérocyte), les triglycérides ne sont pas seulement constitués d'acides gras d'origine alimentaire, mais aussi d'acides gras endogènes. Ceux-ci peuvent être apportés par le sang qui irrigue la muqueuse intestinale, par la bile, par les cellules intestinales desquamées ou bien être synthétisés dans l'entérocyte ; ces lipides endogènes s'ajoutent à ceux d'origine alimentaire et participent aux mêmes processus.

Les triglycérides exogènes qui comportent des acides gras courts et moyens n'ont pas le même sort que ceux qui sont constitués d'acides gras longs. Dans la lumière intestinale, les premiers sont libérés plus rapidement que les seconds, quelle que soit leur localisation dans la molécule de triglycérides. Comme leur polarité est plus élevée que celle des acides gras longs, ils sont absorbés sans passer obligatoirement par la phase micellaire et franchissent aisément la «couche non agitée»; ils sont peu estérifiés dans la cellule. Ils sont transportés sous forme libre vers le foie par les albumines du sang portal, en quantités d'autant plus grandes que leur chaîne est plus courte. Plus leur chaîne est longue, plus ils ont la capacité d'être incorporés dans les triglycérides et d'emprunter la voie lymphatique en plus grandes proportions. 


\section{References}

AHRENS E. J., BORGSTROM B., 1956. Exchange of free fatty acids and glyceride fatty acids during fat digestion in the human intestine. J. biol. Chem., 219, 665-675.

AILHAUD G., SAMUEL D., DESNUELLE P., 1963. Localisation subcellulaire de l'acyl-CoA synthétase de la muqueuse intestinale. Biochim. Biophys. Acta, 67, 150-152.

ARVIDSON G. A. E., NILSSON A., 1972. Formation of lymph chylomicron phosphatidylcholines in the rat during the absorption of safflower oil or triolein. Lipids, 7, 344-348.

BAXTER J. H., 1966. Origin and characteristics of endogenous lipid in thoracic duct lymph in rat. J. Lipid Res., 7, 158-166.

BENNETT S., 1964. Intestinal absorptive capacity and site of absorption of fat under steady-state conditions in the unanaesthetized rat. Quart. J. exp. Physiol., 49, 210-218.

BERNARD A., CARLIER H., CASELLI C., BEZARD J., 1979a. Effect of acetocycloheximide (ACH) on intestinal absorption of lipids in the rat. Gastroenterol. clin. biol., 3, 169.

BERNARD A., CASELLI C., CARLIER H., BEZARD J., 1979b. Electron microscopic investigation of the intestinal epithelial cells and the lipoprotein particles of lymph in rats after ingestion of peanut, canbra and rapeseed oil in the diet. J. Physiol. (Paris) (in press).

BERNARD C., 1856. Mémoire sur le pancréas et sur le rôle du suc pancréatique dans les phénomènes digestifs, particulièrement dans la digestion des matières grasses neutres. Comptes-Rendus, Suppl. 43, 379-563, Baillière ed.

BICKERSTAFFE B., ANNISON E. F., 1969. Triglyceride synthesis by the small intestinal epithelium of the pig, sheep and chicken. Biochem. J., 111, 419-429.

BLANCHETTE-MACKIE E. J., SCOW R. O., 1973. Effects of lipoprotein lipase on the structure of chylomicrons. J. Cell Biol., 58, 689-708.

BLOMSTRAND R., 1954. On the intestinal absorption of phospholipids in the rat. Acta chem. scand., 8, 1945-1946.

BLOMSTRAND R., 1955. Transport form of decanoic acid-1 ${ }^{14} \mathrm{C}$ in the lymph during intestinal absorption in the rat. Acta physiol. scand., 34, 67-70.

BLOMSTRAND R., AHRENS E. H. Jr., 1958. Absorption of fats : Studies in a patient with chyluria. J. biol. Chem., 233, $321-326$.

BLOMSTRAND R., BORGSTROM B., DAHLBACK O., 1959. Extent of total hydrolysis of dietary glycerides during digestion and absorption in the human. Proc. Soc. exp. Biol. N. Y., 102, 204206.

BLOMSTRAND R., THORN N. A., AHRENS E. H. Jr., 1958. The absorption of fats : Studies in a patient with chyluria. Amer. J. Med., 24, 958-966.

BLOOM B., CHAIKOFF I. L., REINHARDT W. O., 1951. Intestinal lymph as pathway for transport of absorbed fatty acids of different chain lengths. Amer. J. Physiol., 166, 451-455.

BOQUILLON M., PARIS R., CLÉMENT J., 1972. Composition, particle size and role in dietary fat transport of two different lipoproteins of the intestinal lymph. Lipids, 7, 409-414.

BOQUILLON M., CARLIER H., CLÉMENT J., 1974. Effect of various dietary fats on the size and distribution of lymph fat particles in rat. Digestion, 10, 255-266.

BORGSTROMM B., 1952a. On the mechanism of the intestinal fat absorption. III. Metabolism of lipids. 4. Acta physiol. scand., 25, 140-149.

BORGSTRÖM B., 1952b. On the mechanism of the intestinal fat absorption. IV. Metabolism of lipids. 6. Acta physiol. scand., 25, 291-314.

BORGSTRÖM B., 1952c. On the action of pancreatic lipase on triglycerides in vivo and in vitro. Acta physiol. scand., 25, 328-347.

BORGSTRÖM B., 1953a. On the mechanism of the intestinal fat absorption. $V$. The effect of bile diversion on fat absorption in the rat. Acta. physiol. scand., 28, 279-286.

BORGSTROMM B., 1953b. On the mechanism of the hydrolysis of glycerides by pancreatic lipase. Acta chem. scand., 7, 557-560.

BORGSTROMM B., 1954a. The formation of new glyceride-ester bounds during digestion of glycerides in the lumen of the small intestine of the rat. Arch. Biochem. Biophys., 49, 268-275.

BORGSTROMM B., 1954b. On the mechanism of pancreatic lipolysis of glycerides. Biochim. biophys. acta, 13, 491-504. 
BORGSTRÖM B., 1955. Transport form of ${ }^{14} \mathrm{C}$-decanoic acid in portal and inferior vena cava blood during absorption in the rat. Acta physiol, scand., 34, 71-74.

BORGSTRÖM B., 1974. Fat digestion and absorption, in SMYTH D. H., Biomembranes, 4B, 556620, Plenum Press, London, New York.

BORGSTRÖM B., 1977. Physico-chemical characteristics of the lipase-colipase-bile salt system. Exp. Ann. Biochim. Med. 173-182, Masson, Paris, New York, Barcelone, Milan.

BORGSTRÖM B., DAHLQVIST A., LUNDH G., SJOVALL J., 1957. Studies on intestinal digestion and absorption in the human. J. clin. Invest., 36, 1521-1536.

BORGSTRÖM B., LINDHE B. A., WLODAWER P., 1958. Absorption and distribution of cholestérol${ }^{4-14} \mathrm{C}$ in the rats. Proc. Soc. exp. Biol. Med., 99, 365.

BOUCROT P., CLÉMENT J., 1965a. Apport d'acides gras endogènes dans la lymphe chez le rat après administration d'un repas contenant des triglycérides mixtes stéarique ${ }^{14} \mathrm{C}$-oléique ${ }^{3} \mathrm{H}$. C. R. Acad. Sci. Paris, 260, 4083-4086.

BOUCROT P., CLÉMENT J., 1965b. Transformations métaboliques subies par les acides palmitique ef stéarique au cours de leur digestion ef absorption. Arch. Sci. physiol., 19, 181-196.

BOUCROT P., CLÉMENT J., 1969. Participation des acides gras du sang ef de la bile à la formation des lipides endogènes de la lymphe chez le rat qui ingère un repas contenant des graisses. Biochim. biophys. Acta, 187, 59-72.

BRAGDON J. H., KARMEN A., 1960. The fatty acid composition of chylomicrons of chyle and serum following the ingestion of different oils. J. Lipid Res., 1, 167-170.

BRECKENRIDGEW. C., KUKSIS A., 1975a. Diacylglycerol biosynthesis in everted sacs of rat intestinal mucosa. Can. J. Biochem., 53, 1170-1183.

BRECKENRIDGE W. C., KUKSIS A., 1975b. Triacylglycerol biosynthesis in everted sacs of rat intestinal mucosa. Can. J. Biochem., 53, 1184-1195.

BRINDLEY D. N., 1974. The intracellular phase of fat absorption. In SMYTH D. H. Biomembranes, 4B, 621-671, Plenum Press, London, New York.

BRINDLEY D. N., HÜBSCHER G., 1965. The intracellular distribution of the enzymes catalysing the biosynthesis of glycerides in the intestinal mucosa. Biochem. biophys. Acta, 106, 495-509.

BROCKERHOFF H., 1970. Substrate specificity of pancreatic lipase. Influence of the structure of fatty acids on the reactivity of esters. Biochim. biophys. Acta, 212, 92-101.

BROWN J. L., JOHNSTON J. M., 1963. Distribution of fatty acids in triglycerides synthesized from monoglycerides. Biochim. biophys. Acta, 70, 603-605.

BUELL G. C., REISER R., 1959. Glyceride-glycerol precursors in the intestinal mucosa. J. Biol. Chem., 234, 217-219.

BURR W. W. Jr., McPHERSON J. C., TIDWELL H. C., 1960. Secretion of labeled blood lipids into the intestine. J. Nutr., 70, 171-175.

CARDELL R. R., BADENHAUSEN S., PORTER K. R., 1967. Intestinal triglyceride absorption in the rat. J. Cell Biol., 34, 123-155.

CARLIER H., 1971. Absorption en fonction du temps par un segment d'intestin de rat in situ de monopalmitine, d'acide palmitique ef d'acide oléique tritié. J. Microscopie, 12, 193-204.

CARLIER H., 1973. Efude radioautographique en microscopie électronique de l'absorption intestinale des acides caprique ef oléique chez le rat. Th. Etat, Dijon.

CARLIER H., BEZARD J., 1975. Electron microscope autoradiographic study of intestinal absorption of decanoic and octanoic acids in the rat. J. Cell Biol., 65, 383-397.

CARLIER H., CLÉMENT G., NOIROT-THIMOTHÉE C., 1969. Application de la technique de radioautographie en microscopie électronique à l'étude de l'absorption intestinale des lipides chez le rat. C. R. Acad. Sci. Paris, 268, 1627-1629.

CHAPUS C., SARI H., SEMERIVA M., DESNUELLE P., 1975. Role of colipase in the interfacial adsorption of pancreatic lipase at hydrophobic interfaces. FEBS Lett., 58, 155-158.

CHEVALLIER F., VYAS M., 1963. Les origines du cholestérol du chyle - mises en évidence à l'aide de la méthode des indicateurs nucléaires. Bull. Soc. Chim. biol., 45, 253-275.

CHEVALLIER F., LUTTON C., 1972. Mouvements des stérols dans le tube digestif du rat. Absorption du cholestérol de synthèse. Biochim. biophys. Acła, 274, 382-411.

CHEVALLIER F., LUTTON C., 1973. The intestine is the major site of cholesterol synthesis in the rat. Nature New Biol., 242, 61-62.

CLARK B., HÜBSCHER G., 1960. Biosynthesis of glycerides in the mucosa of the small intestine. Nature, London, 185, 35-37. 
CLÉMENT G., CLÉMENT J., BEZARD J., 1962. Action of human pancreatic lipase on synthetic mixed symmetrical triglycerides of long-chain acids and butyric acid. Biochem. biophys. Res. Comm., 8, 238-242.

CLÉMENT G., CLÉMENT J., COUREL E., KLEPPING J., BRIET S., 1963. Absorption des acides gras à chaînes moyennes et courtes, 172-179. In FRAZER A. C., Biochemical problems of lipids, Elsevier, Amsterdam.

CLÉMENT G. E., MEAD J. F., 1959. Study of lymph lipids following administration of oleic-1 $1.4 \mathrm{C}$ acid with or without cholesterol. Proc. Soc. exp. Biol. Med., 100, 285-288.

CLÉMENT G., PARIS R., 1964. Absorption d'acides gras et de monoglycérides marqués par un segment d'intestin in situ. C. R. Acad. Sci. Paris, 258, 6006-6009.

CLÉMENT J., 1976. Digestion et absorption des triglycérides alimentaires. J. Physiol. (Paris), 72, 137170.

CLÉMENT J., CLÉMENT G., BRASSEUL G., 1959. Etude des esters de cholestérol et des glycérides de la lymphe chez le rat en fonction des lipides du régime. C. R. Acad. Sci. Paris, 248, 746749.

CONIGLIO J. G., CATE D. L., 1958. The distribution of palmitic and stearic acids in liver, intestine and carcass of intact normal fasted rats. J. biol. Chem., 232, 361-368.

COTTON P. B., 1972. Non-dietary lipid in the intestinal lumen. Gut, 13, 675-681.

COUREL E., CLÉMENT J., 1964 . Influence de la graisse alimentaire sur la composition en acides gras du chyle ; importance de l'apport d'acides gras endogènes. Arch. Sci. physiol., 18, 419-441.

CROFT D. N., COTTON P. B., 1973. Gastrointestinal cell loss in man : Its measurement and significance. Digestion, 8, 144-160.

DAWSON A. M., ISSELBACHER K. J., 1960. The esterification of palmifate 1-C ${ }^{14}$ by homogenates of intestinal mucosa. J. clin. Invest., 39, 150-160.

DERMER G. B., 1968. An autoradiographic and biochemical study of oleic acid absorption by intestinal slices including determinations of lipid loss during preparation for electron microscopy. J. Ultrastruct. Res., 22, 312-325.

DESNUELLE P., NAUDET M., CONSTANTIN M. J., 1951. Sur un nouveau type de lipolyse in vitro, une lipolyse génératrice de glycérol. Biochim. biophys. Acta, 7, 251-256.

DESNUELLE P., NAUDET M., ROUZIER J., 1947. Sur la formation de glycérides partiels au cours de I'hydrolyse des triglycérides par la lipase pancréatique. C. R. Soc. Biol., 141, 1242-1244.

DESNUELLE P., NAUDET M., ROUZIER J., 1948. Etude quantitative de la formation de glycérides partiels au cours de l'hydrolyse fermentaire des triglycérides. Biochim. biophys. Acta, 2, $561-574$.

DI COSTANZO G., CLÉMENT J., 1965a. Incorporation in vivo des acides oléique, stéarique el palmitique tritiés dans les lipides de la lumière ef de la muqueuse intestinales chez le rat. Importance de l'apport des acides gras endogènes. Bull. Soc. Chim. biol., 47, 57-68.

DI COSTANZO G. CLÉMENT J., 1965b. Incorporation in vivo des acides oléique, stéarique et palmitique tritiés dans les divers phospholipides de la muqueuse intestinale chez le rat. Influence de la composition en acides gras du régime sur la répartition de ces phospholipides. Bull. Soc. Chim. biol., 47, 833-849.

DIETSCHY J. M., 1968. The role of bile salts in controlling the rate of intestinal cholesterogenesis. J. clin. Invest., 47, 286-300.

DIETSCHY J. M., SIPERSTEIN M. D., 1965. Cholesterol synthesis by the gastrointestinal tract : Localization and mechanisms of control. J. clin. Invest., 44, 1327-1331.

DI Nella R. R., MENG H. C. et PARK C., 1959. Properties of infestinal lipase. J. biol. Chem., 235, 3076-3081.

ENTRESSANGLES B., PASERO L., SAVARY P., SARDA L., DESNUELLE P., 1961, Influence de la nature des chaînes grasses sur la vitesse de leur hydrolyse par la lipase pancréatique. Bull. Soc. Chim. biol., 43, 581-591.

FAVARGER P., 1958. L'absorption intestinale ef l'utilisation des graisses. Ist. Symph Mainz. In : Wiss. verôfftl. Disch. Ges. Ernährung, Dietrich Steinkopff, Darmstadt, 1.

FAVARGER P., 1960. Absorption des lipides alimentaires. Gastroenterologia, 2, 4-27.

FELKER T. E., FAINARU M., HAMILTON R. L., HAVEL R. J., 1975. Secretion of the arginine-rich and $A_{1}$ apolipoproteins by the isolated perfused rat liver. J. Lipid Res., 16, 465-473.

FERNANDES J., VAN DE KAMER J. H., WEIJERS H. A., 1955. The absorption of fats studied in a child with chylothorax. J. clin. Invest., 34, 1026-1036. 
FRANKS J. J., RILEY E. M., ISSELBACHER K. J., 1966. Synthesis of fatty acids by rat intestine in vitro. Proc. Soc. exp. Biol. Med., 121, 322-327.

FRIEDMAN H. 1., CARDELL R. R. Jr., 1972. Morphological evidence for the release of chylomicra from intestinal absorptive cells. Exp. Cell Res., 75, 57-62.

GANGL A., OCKNER R. K., 1975. Intestinal metabolism of plasma free fatty acids : Infracellular compartmentation and mechanisms of control, J. clin. Invest., 55, 803-813.

GANGULY J., 1960. Mechanism of fatty acid synthesis. VIl. Biosynthesis of fatty acids from malonylcoenzyme A., Biochim. biophys. Acta, 40, 110-118.

GLICKMAN R. M., 1976. Chylomicron formation by the intestine. In ROMMEL K., GOEBELL H., BOHMER R., Lipid absorption : biochemical and clinical aspects, MTP Press Ltd, St Leonard's House, Lancaster, Angleterre.

GLICKMAN R. M., GREEN P. R., 1977. The intestine as a source of apolipoprotein A. Proc. nat. Acad. Sci., 74, 2569-2573.

GLICKMAN R. M., KIRSCH K., ISSELBACHER K. J., 1972. Fat absorption during inhibition of protein in synthesis : Studies of lymph chylomicrons. J. clin. Invest., 51, 356-363.

GOTTENBOS J. J., THOMASSON H. J., 1963. The fatty acid composition of thoracic lymph fats of rats fed single triglycerides, 272-279. In FRAZER A. C., Biochemical problems of lipids, Elsevier, Amsterdam,

GREEN P. H. R., GLICKMAN R. M., SAUDEK C. D., BLUM C. B., TALL A. R., 1979. Human intestinal lipoproteins : Studies in chyluric subjects. J. clin. Invest., 64, 233-242.

HAJRA A. K., AGRANOFF B. W., 1968a. Characterization of a ${ }^{32}$ P-labeled lipid from guinea pig liver mitochondria. J. biol. Chem., 243, 1617-1622.

HAJRA A. K., AGRANOFF B. W., 1968b. Reduction of palmitoyldihydroxyacetone phosphate by mitochondria. J. biol. Chem., 243, 3542-3543.

HAMOSH M., SCOW R. O., 1973. Lingual lipase and its role in the digestion of dietary lipid. J. clin. Invest., 52, 88-95.

HAMOSH M., KLAEVEMAN H. L., WOLF R. O., SCOW R. O., 1975. Pharyngeal lipase and digestion of dietary triglyceride in man. J. clin. Invest., 55, 908-913.

HAVEL R. J., KANE J. P., BALASSE E. O., SEGEL N., BASSO L. V., 1970. Splanchnic metabolism of free fatty acids and production of very low density lipoproteins in normotriglyceridemic and hypertriglyceridemic humans. J. clin. Invest., 49, 2017-2035.

HAVEL R. J., KANE J. P., KASHYAP M. L., 1973. Inferchange of apolipoproteins between chylomicrons and high density lipoproteins during alimentary lipemia in man. J. clin. Invest., 52, 3238.

HERNELL O., OLIVECRONA T., 1974. Human milk lipases. II. Bile salt-stimulated lipase. Biochim. biophys. Acta, 369, 234-244.

HIGGINS J. A., BARNETT R. J., 1971. Fine structural localization of acyltransferases. The monoglyceride and $\alpha$-glycerophosphate pathways in intestinal absorptive cells. J. Cell Biol., 50, $102-$ 120.

HOFMANN A. F., BORGSTRÖM B., 1963. The distinctive detergent properties of conjugated bile salts and their relation to the role of bile salts in fat digestion. J. clin. Invest., 42, 942.

HOFMANN A. F., MEKHJIAN H. S., 1973. Bile acids and the intestinal absorption of fat and electrolytes in health and disease, 103-152. In NAIR P. and KRITCHEVSKY D., The bile acids, Plenum Press, New York.

HOLT R. R., WU A. L., BENNETT-CLARK S., 1979. Apoprotein composition and turnover in rat intestinal lymph during steady-state triglyceride absorption. J. Lipid Res., 20, 494-502.

HOVING J., VALKEMA A. J., 1969. Effect of dietary fat content on the site of fat absorption in hamster small intestine in vitro. Biochim. Biophys. Acta, 187, 53-58.

HÜLSMANN W. C., KURPERSHOEK-DAVIDOV, 1976. Topographic distribution of enzymes involved in glycerolipid synthesis in rat small intestinal epithelium. Biochim. Biophys. Acta, 450, 288-300.

ISSELBACHER K. J., BUDZ D. M., 1963. Synthesis of lipoproteins by rat intestinal mucosa. Nature, London, 200, 364-365.

JOHNSTON J. M., 1977. Gastrointestinal tissue, 151-188. In SNYDER F., Lipid metabolism in mammals, Plenum Press, New York and London.

JOHNSTON J. M., BEARDEN J. H., 1960a. Phosphatidic acids as intermediates in fatty acid absorption. Arch. Biochem. Biophys., 90, 57-62. 
JOHNSTON J. M., BEARDEN J. H., 1960b. The labeling of phosphatidic acids during the absorption of fatty acids. Fed. Proc., 19, 230.

JOHNSTON J. M., BROWN J. L., 1962. Intestinal utilization of doubly labeled $\alpha$-monopalmitin. Biochim. biophys. Acta, 59, 500-501.

JOHNSTON J. M., RAO G. A., REISTAD R., 1965. Species difference in the synthesis of triglycerides from monoglycerides. Biochim. biophys. Acta, 98, 432-434.

KAYDEN H. J., KARMEN A., DUMONT A. E., 1963. Alterations in the fatty acid composition of human lymph and serum lipoproteins by single feedings. J. clin. Invest., 42, 1373-1381.

KAYDEN H. J., KARMEN A., DUMONT A. E., BRAGDON J., 1960. Fatty acid patferns of human lymph and serum after corn oil or coconut oil feeding. J. clin. Invest., 39, 1001.

KERN F. Jr., BORGSTRÖM B., 1965. Quantitative study of the pathways of triglyceride synthesis by hamster intestinal mucosa. Biochim. biophys. Acta, 98, 520-531.

KESSLER J. E., NARCESSIAN P., MAUDLIN D. P., 1975. Biosynthesis of lipoprotein by intestinal epithelium site of synthesis and sequence of association of lipid, sugar and protein moities. Gastroenterology, 68 (abstr.).

KORNBERG A., PRICER W. E., 1953. Enzymatic synthesis of the coenzyme A derivatives of long chain fatty acids. J. biol. Chem., 204, 329-343.

KOSTNER G., HOLASEK A., 1972. Characterization and quantitation of apoproteins from human chylomicrons. Biochemistry, 11, 1217-1223.

LAIRON D., NALBONE G., LAFONT H., LEONARDI J., DOMINGO N., HAUTON J. C., VERGER R., 1978. Possible roles of bile lipids and colipase in lipase adsorption. Biochemistry, 17, 5263 5269.

LEVI A. J., GATMAITAN Z., ARIAS I. M., 1969. Two hepatic cytoplasmic profein fractions, Y and Z, and their possible role in the hepatic uptake of bilirubin, sulfobromophtalein and other anion. J. clin. Invest., 48, 2156-2167.

LEVY R. E., FREDRICKSON D. S., LESTER L., 1966. The lipoproteins and lipid transport in abetalipoproteinemia. J. clin. Invest., 45, 531-541.

LUTTON C., BROT-LAROCHE E., 1979. Biliary cholesterol absorption in normal and L-thyroxinefed rats. Lipids, 14, 441-446.

MAHLEY R. W., BENNETT B. D., MORRE D. J., GRAY M. E., THISTLEWAITE W., LEQUIRE V. S., 1971. Lipoproteins associated with the Golgi apparatus isolated from epithelial cells of rat small intestine. Lab. Invest., 25, 435-444.

MANSBACH C. M., 1973. Complex lipid synthesis in hamster infestine. Biochim. biophys. Acta, 296, 386400.

MARSH J. B., 1976. Apoproteins of the lipoproteins in a non-recirculating perfusate of rat liver. J. Lipid Res., 17, 85-90.

MATTSON F. H., BECK L. W., 1955. The digestion in vitro of triglycerides by pancreatic lipase. J. biol. Chem., 214, 115-125.

MATTSON F. H., BECK L. W., 1956. The specificity of pancreatic lipase for the primary hydroxyl groups of glycerides. J. biol. Chem., 219, 735-740.

MATTSON F. H., BENEDICT J. H., MARTIN J. B., BECK L. W., 1952. Intermediates formed during the digestion of triglycerides. J. Nutr., 48, 335-344.

MATTSON F. H., VOLPENHEIN R. A., 1962. Rearrangement of glyceride fatty acids during digestion and absorption. J. biol. Chem., 237, 53-55.

MATTSON F., VOLPENHEIN, R. A., 1964. The digestion and absorption of triglycerides. J. biol. Chem., 239, 2772-2777.

MATTSON F., VOLPENHEIN R. A., 1968. Hydrolysis of primary and secondary esters of glycerol by pancreatic juice. J. Lipid Res., 9, 79-84.

MAYLIE M. F., CHARLES M., GACHE C., DESNUELLE P., 1971. Isolation and partial identification of a pancreatic colipase. Biochim. biophys. Acta, 229, 286-289.

METAIS P., BACH A., WARTER J., 1967. Comparaison par l'éłude du ${ }^{14} \mathrm{CO}_{2}$ de l'air expiré, de l'utilisation des graisses à acides gras longs, moyens ou courts. C. R. Soc. Biol., 161, 1372-1376.

MOREHOUSE M. G., SKIPSKI W. P., SEARCY R. I., SPOLTER L., 1956. Absorption and distribution in the rat of lipids utilizing labelled glycerides and components, 341-346. In POPJACK G., LEBRETON E., Biochemical problems of lipids, Butterworth Sci. Publ.

MORGAN R. G. H., BARROWMAN J., BORGSTRÖM B., 1969. The effect of sodium faurodeoxycho- 
late and $\mathrm{pH}$ on the gel filtration. Behaviour of rat pancreatic protein and lipases. Biochim. biophys. Acto, 175, 65-75.

NILSSON A., 1968. Intestinal absorption of lecithin and lysolecithin by lymph fistula rats. Biochim. biophys. Acfa, 152, 379-390.

OCKNER R. K., HUGHES F. B., ISSELBACHER K. J., 1969a. Very low density lipoproteins in intestinal lymph : Role in triglyceride and cholesterol transport in the fasting state. J. clin. Invest., 48, 1079-1088.

OCKNER R. K., HUGHES F. B., ISSELBACHER K. J., 1969b. Very low density lipoproteins of intestinal lymph : Role in triglyceride and cholesterol transport during fat absorption. J. clin. invest., 48, $2367-2373$.

OCKNER R. K., JONES L., 1970. An electron-microscopic and functional study of very low density lipoproteins in intestinal lymph. J. Lipid Res., 11, 283-292.

OCKNER R. K., MANNING J. M., POPPENHAUSEN R. B., HO W. K., 1972. A binding protein for fatty acids in cylosol of intestinal mucosa, liver, myocardium and other tissues. Science, 177, 56-58.

OCKNER R. K., PITTMAN J. P., YAGER J. L., 1972. Differences in the intestinal absorption of safurated and unsaturated long chain fatty acids. Gastroenterology, 62, 981-992.

O'DOHERTY P. J. A., KUKSIS A., 1975. Stimulation of triacylglycerol synthesis by protein in rat liver and intestinal mucosa. FEBS Letfers, 60, 256-258.

PALAY S. L., KARLIN L. J., 1959. An electron microscopic study of the intestinal villus. Il. The pathway of fat absorption. J. biophys. biochem. Cytol., 5, 373-384.

PALTAUF F., ESFANDI F., HOLASEK A., 1974. Stereospecificity of lipases. Enzyme hydrolysis of enantiomeric alkyl diacylglycerols by lipoprotein lipase, lingual lipase and pancreatic lipase. FEBS Letfers, 40, 119-123.

PARIS R., CLÉMENT G., 1965. Participation of phosphorylated intermediates in in vivo synthesis of triglycerides from 1-monoglycerides in raf intestinal mucosa. Proc. Soc. exp. Biol. Med., 119, 591-593.

PARIS R., CLÉMENT G., 1968. Biosynthèse de triglycérides à partir de 2-monopalmitine doublement marquée dans la muqueuse intestinale de rat. Biochim. biophys. Acla, 152, 63-74.

PARIS R., CLÉMENT G., 1969. Biosynthesis of lysophosphatidic acid from ATP and 1-monoolein by subcellular particles of intestinal mucosa. Proc. Soc. exp. Biol. Med., 131, 363-365.

PORTE D., ENTENMAN C., 1965. Fatty acid metabolism in segments of rat intestine. Amer. J. Physiol., 208, 607-614.

RAO G. A., SORRELS M. F., REISER R., 1970. Biosynthesis of triglycerides from triose phosphates by microsomes of the intestinal mucosa. Lipids, 5, 762-764.

REDGRAVE T. G., 1971. Association of Golgi membranes with lipid droplets (prechylomicrons) from within intestinal epithelial cells during absorption of fat. Austr. J. exp. Biol. med. Sci., 49, 209-224.

REEVE J., FRANKS J. J., 1968. Fatty acid synthesis by jejunal slices from rats fed medium and long chain triglycerides. Amer. J. Physiol., 214, 1425-1428.

REISER R., BRYSON M. J., CARR M. J., KUIKEN K. A., 1952. The intestinal absorption of triglycerides. J. biol. Chem., 194, 131-138.

REISER R., FU H. C., 1966. Acyl-group exchange in the intestinal lumen during fat digestion. Biochim. biophys. Acta, 116, 563-569.

RODBELL M., FREDRICKSON D. S., 1959. The nature of the proteins associated with dog and human chylomicrons. J. biol. Chem., 234, 562-566.

RODBELL M., FREDRICKSON D. S., ONO K., 1959. Metabolism of chylomicron proteins in the dog. J. biol. Chem., 234, 567-571.

RODGERS J. B., BOCHENEK W., 1970. Localization of lipid re-esterifying enzymes on the small intestine. Effects of jejunal removal on ileal activities. Biochim. biophys. Acta, 202, 426-435.

ROHEIM P. S., GIDEZ L. I., EDER H. A., 1966. Extrahepatic synthesis of lipoproteins of plasma and chyle : Role of the intestine. J. clin. Invest., 45, 297-300.

SABESIN S. M., 1976. Ultrastructural aspects of the intracellular assembly, transport and exocytosis of chylomicrons by rat intestinal absorptive cells, 113-150. In ROMMEL K., GOEBELL H., BOHMER R., Lipid absorption : biochemical and clinical aspects, MTP Press Lted, St Leonard's House, Lancaster. 
SALLÉE V. L., DIETSCHY J. M., 1973. Deferminants of intestinal mucosal uptake of short - and medium - chain fatty acids and alcohols. J. Lipid Res., 14, 475-484.

SAVARY P., CONSTANTIN M. J., DESNUELLE P., 1961. Sur la structure des triglycérides des chylomicrons lymphatiques du rat. Biochim. biophys. Acta, 48, 562-571.

SAVARY P., DESNUELLE P., 1956. Sur quelques éléments de spécificité pendant l'hydrolyse enzymatique des triglycérides. Biochim. biophys. Acta, 21, 349-360, et C. R. Acad. Sci., Paris, 240, 2571 (1955).

SAVARY M., CONSTANTIN M. J., 1967. Some experimental data on the endogenous chains in the triglycerides of rat thoracic duct lymph. Biochim. biophys. Acta, 144, 549-555.

SCHACHTER H., RODEN L., 1973. The biosynthesis of animal glycoproteins. In FISHMAN W. H., Metabolic conjugation and metabolic hydrolysis, vol. III, 2-149, Acad. Press, New York.

SCHILLER C. M., DAVID J. S. K., JOHNSTON J. M., 1970. The subcellular distribution of triglyceride synthetase in the intestinal mucosa. Biochim. biophys. Acta, 210, 489-492.

SCOW R. O., STEIN Y., STEIN O., 1967. Incorporation of diefary lecithin and lyso lecithin into lymph chylomicrons in the rat. J. biol. Chem., 242, 4919-4925.

SENIOR J. R., ISSELBACHER K. J., 1961a. Fatty acid activation and glyceride synthesis by subcellular particles of rat intestinal mucosa. Fed. Proc., 20, 245.

SENIOR J. R., ISSELBACHER J. K., 1961b. Formation of higher glycerides from monopalmitin and palmifyl-CoA by microsomes of rat intestinal mucosa. Biochem. biophys. Res. Comm., 6, 274-278.

SENIOR J. R., ISSELBACHER K. J., 1961c. Direct esterification ef monoglycerides with palmityl coenzyme A by intestinal epithelial subcellular fractions. J. biol. Chem., 237, 1454-1459.

SENIOR J. R., ISSELBACHER K. J., 1963. Demonstration of an intestinal monoglyceride lipase : An enzyme with a possible role in the intracellular completion of fat digestion. J. clin. Invest., 42, 187-195.

SHIAU Y. F., LONG W. B., WEISS J. B., 1978. Effect of sugar and monoglyceride on fatty acid esterification. Amer. J. Physiol., 234, E 236-242.

SIMMONDS W. J., 1974. Absorption and lipids. In, JACOBSEN E. D., SHANBOUR L. L., MTP International review of science ; physiology series one, vol. 4, Gastro-intestinal Physiology, Butterworths and Baltimore, Univ. Park Press, London, Pp. 343-376.

SIMMONDS W. J., 1976. Uptake of fatty acid and monoglyceride, 51-64. In ROMMER K., GOEBELL H., BOHMER R., Lipid absorption : biochemical and clinical aspects, MTP Press L†d S† Leonard's House, Lancaster, England.

SIMMONDS W. J., REDGRAVE T. G., WILLIX R. L. S., 1968. Absorption of oleic and palmitic acids from emulsions and micellar solutions. J. clin. Invest., 47, 1015-1025.

SJÖSTRAND F. S., 1963. The fine structure of the columnar epithelium of the mouse intestine, with special reference to fat absorption. In FRAZER A. C., Biochemical problems of lipids, Elsevier, Amsterdam, 474, 91-115.

STRAUSS E. W., 1968. Morphological aspects of triglyceride absorption, 1377-1406. In CODE C. F., WEIDEL W., Handbook of physiology, sect. 6, alimentary canal, vol. 3, Intestinal absorption, Williams et Wilkins Co, Baltimore, Md.

STRAUSS E. W., ITO S., 1964. Autoradiography and biochemical study of linoleic acid ${ }^{14} \mathrm{C}$ absorption by hamster intestine from mixed micelles in vitro. J. Cell Biol., 27, 101A.

SWELL L., FLICK D. F., FIELD H. Jr., TREADWELL C. R., 1955. Role of fat and fatty acid in absorption of dietary cholesterol. Amer. J. Physiol., 180, 124-128.

TATTRIE N. H., BAILEY R. A., KATES M., 1958. The action of pancreatic lipase on stereoisomeric triglycerides. Arch. Biochem. Biophys., 78, 319-327.

ULRICH C., BOUCROT P., CLÉMENT J., 1974. Site of biliary phospholipid absorption in the small intestine of the rat. Biochimie, 56, 429-434.

VERDINO B., BLANK M. L., PRIVETT O. S., 1965. Endogenous lipid composition of the intestinal lymph of rats raised on fat free, lard or corn oil diets. J. Lipid Res., 6, 356-362.

VODOVAR N., MASSICARD N., FLANZY J., 1968. Formation et rôle des chylomicrons au cours de l'absorption des acides gras à chaîne longue. C. R. Acad. Sci. Paris, 266, 814-817.

VODOVAR N., THIEULIN C., PIHET A., FLANZY J., 1965. Lieu d'absorption des graisses dans l'intestin grêle du porc. Ann. Biol. anim. bioch. Biophys., 5, 249-265.

WEISS S. B., KENNEDY E. P., 1956. The enzymatic synthesis of triglycerides. J. Amer. Chem. Soc., 78, 3550 . 
WESTERGAARD H., DIETSCHY J. M., 1976. The mechanism whereby bile acid micelles increase the rate of fatty acid and cholesterol uptake into the intestinal mucosal cell. J. clin. Invest., 58, 97. 108.

WILSON F. A., DIETSCHY J. M., 1972. Characterization of bile acid absorption across the unstirred water layer and brush border of the rat jejunum. J. clin. Invest, 51, 3015-3026.

WINDMUELLER H. G., HERBERT P., LEVY R. I., 1973. Biosynthesis of lymph and plasma lipoprotein apoproteins by isolated perfused rat liver and intestine. J. Lipid Res., 14, 215-223.

WINDMUELLER H. G., LINDGREN F. T., LOSSOW W. J., LEVY R. I., 1970. On the nature of circulating lipoproteins of intestinal origin in the rat. Biochim. biophys. Acta, 202, 507-516.

WU A. L., WINDMUELLER H. G., 1978. Identification of circulating apolipoproteins synthesized by rat small intestine in vivo. J. biol. Chem., 253, 2525-2528.

ZAKIM D., HO W., 1970. The acyl-CoA carboxylase and fatty acid synthetase activities of rat intestinal mucosa. Biochim. biophys. Acta, 222, 558.

ZILVERSMIT D. B., 1965. The composition and structure of lymph chylomicrons in dog, rat and man. J. clin. Invest., 44, 1610-1622.

ZILVERSMIT D. B., 1968. The surface coat of chylomicron lipid chemistry. J. Lipid Res., 9, $180-186$. 